\title{
Glacier dynamics over the last quarter of a century at Helheim, Kangerdlugssuaq and 14 other major Greenland outlet glaciers
}

\author{
S. L. Bevan, A. J. Luckman, and T. Murray \\ Geography Department, College of Science, Swansea University, Singleton Park, Swansea, SA2 8PP, UK
}

Correspondence to: S. L. Bevan (s.1.bevan@swansea.ac.uk)

Received: 16 April 2012 - Published in The Cryosphere Discuss.: 4 May 2012

Revised: 14 August 2012 - Accepted: 16 August 2012 - Published: 10 September 2012

\begin{abstract}
The Greenland ice sheet is experiencing increasing rates of mass loss, the majority of which results from changes in discharge from tidewater glaciers. Both atmospheric and ocean drivers have been implicated in these dynamic changes, but understanding the nature of the response has been hampered by the lack of measurements of glacier flow rates predating the recent period of warming. Here, using Landsat-5 data from 1985 onwards, we extend back in time the record of surface velocities and ice-front position for 16 of Greenland's fastest-flowing tidewater glaciers, and compare these to more recent data from Landsat-7 and satellite-borne synthetic-aperture radar. Climate re-analysis data and sea surface temperatures from 1982 show that since 1995 most of Greenland and its surrounding oceans have experienced significant overall warming, and a switch to a warming trend. During the period from 1985 to 1995 when Greenland and the surrounding oceans were not warming, major tidewater outlet glaciers around Greenland, including Kangerdlugssuaq and Helheim, were dynamically stable. Since the mid-1990s, glacier discharge has consistently been both greater and more variable. Together, these observations support the hypothesis that recent dynamic change is a rapid response to climate forcing. Both air and ocean temperatures in this region are predicted to continue to warm, and will therefore likely drive further change in outlet glacier discharge.
\end{abstract}

\section{Introduction}

Ice losses from the Greenland ice sheet (GrIS) have been detected from the early 1990s onwards in studies based on altimetry, gravity-field observations, and flux-balance cal- culations (e.g. Pritchard et al., 2009; Schrama et al., 2011; van den Broeke et al., 2011). Low-elevation thinning (below $2000 \mathrm{~m}$ ) has been observed since 1993/94 (Krabill et al., 1999, 2000; Thomas et al., 2006) and is now reaching all latitudes in Greenland, particularly along the south-east and north-west margins (Pritchard et al., 2009) with the percentage of thinning attributable to changing dynamics being far more significant for marine-terminating glaciers (Sole et al., 2008). Observations of gravity-field anomalies by the GRACE satellite system from 2002 confirm that the GrIS is losing mass (Velicogna and Wahr, 2005) and at an increasing rate (Chen et al., 2006; Wouters et al., 2008; Velicogna, 2009). Mass losses were greatest at low elevations (Luthcke et al., 2006) and appeared first in the south-east and later also in the north-west (Luthcke et al., 2006; Khan et al., 2010; Schrama and Wouters, 2011; Schrama et al., 2011).

Mass balance estimates based on flux-balance agree to within $15 \%$ of most GRACE-based estimates for the period from 2003 to 2008 (van den Broeke et al., 2009). The balance has been consistently negative since 1999 (van den Broeke et al., 2011) owing to negative trends in surface mass balance (SMB) (Wake et al., 2009; Hanna et al., 2011) combined with increases in discharge (Rignot et al., 2011). Three major tidewater glaciers experienced large and rapid increases in flow speed: first, Jakobshavn Isbræ in the west, beginning in 1998 (Joughin et al., 2004; Luckman and Murray, 2005), followed by Helheim and Kangerdlugssuaq in 2002 and 2004, respectively (Howat et al., 2005; Luckman et al., 2006). The latter pair have since decelerated (Howat et al., 2007; Murray et al., 2010) but their earlier behaviour meant that, in the south-east, discharge dominated the total mass balance signal, whereas in the north-west the losses were equally distributed between 
surface processes and ice discharge (van den Broeke et al., 2009).

This range of studies has pointed to ice loss concentrated on the marine-terminating outlet glaciers of the south-east and west margins of the ice sheet with changing glacier dynamics playing a key role. The precise mechanisms controlling the response of the outlet glaciers have yet to be fully identified, but all emerging hypotheses invoke a response to increasing atmospheric and/or ocean temperatures resulting in a break-up and retreat of a floating tongue or grounded ice front. The various hypotheses include increased hydrofracturing and calving due to surface meltwater (Benn et al., 2007; Nick et al., 2010; Andersen et al., 2010), reductions in the strength and extent of ice mélange in the fjord (Amundson et al., 2010; Seale et al., 2011), weakening of the ice in the lateral shear margins of the floating tongue (van der Veen et al., 2011), and increased submarine melt rates (Holland et al., 2008; Nick et al., 2012; Rignot et al., 2010; Straneo et al., 2011). Increased submarine melt rates are likely to be the result of fjord-water circulation changes controlled in part by meltwater plumes (Motyka et al., 2003; Rignot et al., 2010; Motyka et al., 2011), the degree of fjord-water stratification, or external factors such as offshore wind events and changes in coastal currents (Murray et al., 2010; Straneo et al., 2010, 2011; Christoffersen et al., 2011). Once thinning and retreat are underway, changing force-balance conditions at the terminus allow upstream glacier acceleration and thinning (Joughin et al., 2004; Howat et al., 2005; Nick et al., 2009).

The proposed connection between terminus thinning, retreat and acceleration allows changing tidewater glacier frontal positions to be used as an indicator or predictor of glacier instability. Surveys based on satellite images show that glaciers in the south-east and west were generally stable between 1972 and 1985 (Howat and Eddy, 2011) with regionally consistent patterns of retreat beginning in 1992 (Moon and Joughin, 2008; Murray et al., 2010; McFadden et al., 2011; Seale et al., 2011). In the south-east the glaciers retreated at an increasing rate until 2005/06 when a general re-advance was established (Moon and Joughin, 2008; Murray et al., 2010; Seale et al., 2011). South-eastern glaciers showed a similar retreat during an early period of warming in the 1930s (Bjork et al., 2012). In the north-west nearly all marine-terminating outlet glaciers showed retreat and thinning at some point between 2000 and 2009 (McFadden et al., 2011); tidewater glaciers north of $69^{\circ} \mathrm{N}$ in the east showed no retreat from 2000 (Seale et al., 2011). Land-terminating glaciers have remained stable since 1992 (Moon and Joughin, 2008; Sole et al., 2008).

Throughout this period of observed changes in the mass balance of the GrIS, air temperatures for Greenland have been increasing (Hanna et al., 2008; Box et al., 2009) with mean summer temperatures now being positively correlated with Northern Hemisphere warming (Hanna et al., 2008), although they have yet to "catch up" (Box et al., 2009). Prior to the early 1990s, from 1961 onwards, southern Greenland summer air temperatures were significantly inversely correlated with the North Atlantic Oscillation (NAO), which was then in a positive mode (Hanna and Cappelen, 2003), implying regional atmospheric circulation patterns were insulating Greenland from northern hemispheric warming.

As well as being coincident with increases in air temperature, the acceleration and retreats of major tidewater glaciers in the east and west show a strong correspondence with warming of adjacent sea-surface temperatures (SSTs) (Hanna et al., 2009) and the subsequent deceleration of the Kangerdlugssuaq and Helheim glaciers with cooling of coastal surface water (Murray et al., 2010). This correspondence leads Hanna et al. (2009) to suggest that SST warming may be important in forcing ice-dynamic changes. In certain locations SSTs may be considered a reasonable proxy for ocean temperatures down to sill depths and hence relevant to submarine melting; Hanna et al. (2009) found this to be the case for SSTs off the coast of western Greenland away from the marginal ice zone by comparison with two 19502007 ocean-depth sections. Andresen et al. (2012) also used SSTs as a proxy for subsurface Atlantic water for a region south of Iceland where they claim Atlantic water extends to the surface.

Like air temperatures, sea surface, subsurface and deeper ocean temperatures around Greenland are also modulated by oscillations in regional atmospheric circulation patterns such as the NAO (Holland et al., 2008) and teleconnections with SSTs as indexed by the Atlantic Multi-decadal Oscillation (AMO) (Sutton and Hodson, 2005). For example, in 19951996 a strong negative NAO allowed warm subpolar waters to move westward around the southern tip of Greenland to the west Greenland continental shelf (Holland et al., 2008). Similarly, the AMO began a warm phase in the mid-1990s meaning that warm SSTs were more likely off the south-east and west coasts of Greenland (Sutton and Hodson, 2005).

The evidence discussed above supports theories that the tidewater-terminating outlet glaciers of the GrIS are responsible for a major part of the recent mass loss and that they respond rapidly and dynamically to changes in air and surrounding ocean temperatures. Constructing a record of changes in glacier dynamics with sufficient spatial extent and temporal resolution to reveal this type of rapid and regionwide response to atmosphere and ocean conditions relies on air- or satellite-borne instrument systems. To date, most glacier surface velocity measurements have been based only on data collected since the launch of ERS-1 in 1992. By coincidence this limitation barely predates the start of the recent period of increasing air and ocean temperatures around Greenland.

In this paper we investigate the extent and magnitude of the air and ocean temperature changes leading up to and during the most recent period of ice loss and test the evidence for a dynamic ice sheet response by extending observations of flow speeds and terminus positions for 16 of Greenland's 


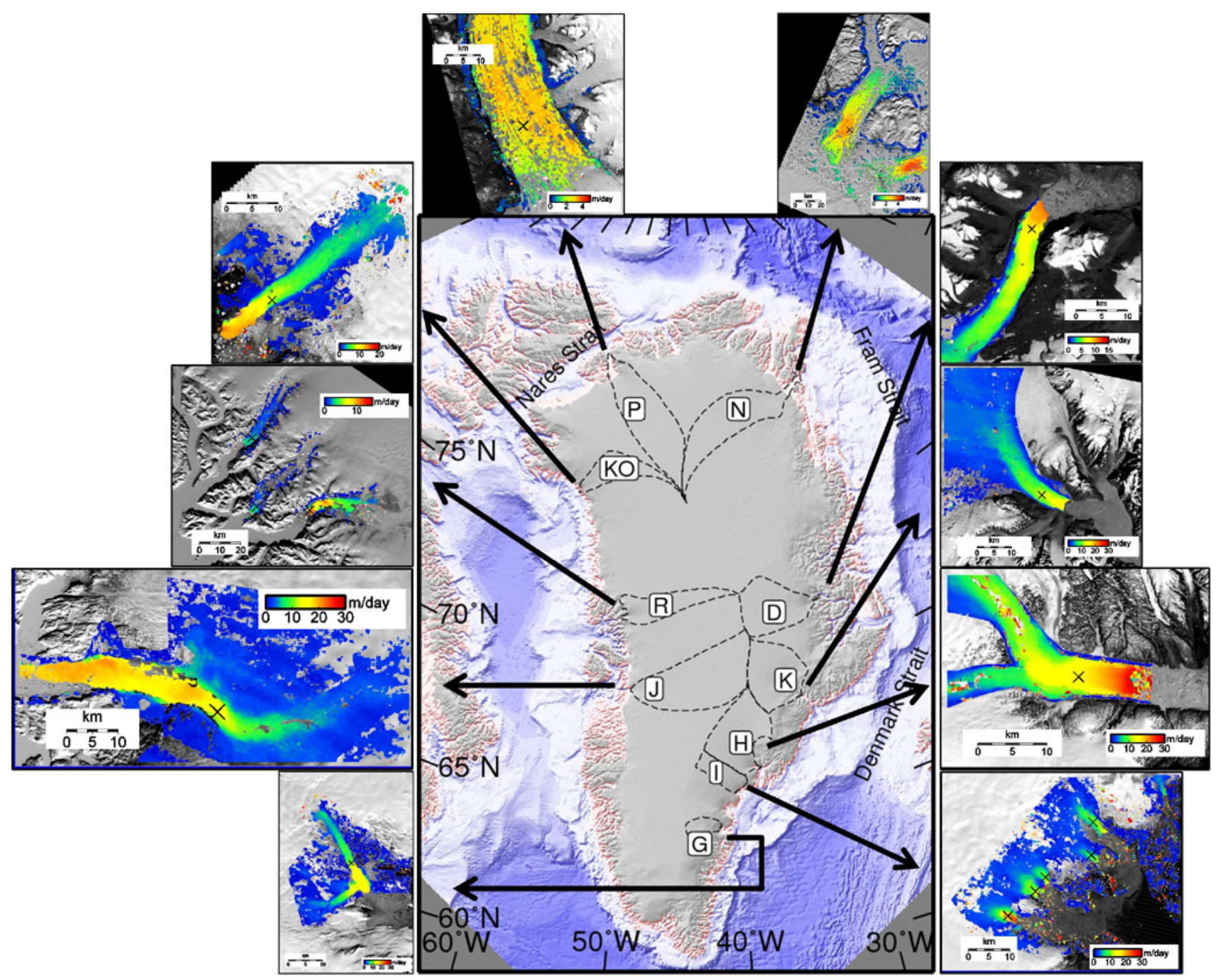

Fig. 1. Outlet glacier catchments. $D=$ Daugaard-Jensen, $K=$ Kangerdlugssuaq, $H=$ Helheim, $I=I k e r t i v a q, G=G y l d e n l o v e, J=J a k o b s h a v n$ Isbræ, $\mathrm{R}=$ Rink Isbræ (including Umiamako and Ingia Isbræ), $\mathrm{KO}=$ Kong Oscar, $\mathrm{P}=$ Petermann, $\mathrm{N}=$ Nioghalvfjerdsbrae. Dates for the sample speed map images are listed in Table 1, and the velocity data extraction points are marked with Xs. Shaded relief and bathymetry based on the International Bathymetric Chart of the Arctic Ocean (Jakobsson et al., 2008).

major glaciers (Fig. 1), including Kangerdlugssuaq, Helheim and Jakobshavn Isbræ, back to 1985. In total, these glaciers drain about $26 \%$ of the GrIS. Our new measurements extend the time series back $7 \mathrm{yr}$ prior to most published measurements, to a time period when both air temperatures and SSTs around Greenland were not warming.

\section{Data and methods}

Tidewater glaciers are now believed to respond rapidly to climate change in ways not dominated by SMB. Therefore, we expect to see a contrast in their behaviour as the Greenland climate moved from a relatively stable period during the 1980s and early 1990s to the more recent years of temper- ature increases. We test this hypothesis by first examining the spatial and temporal characteristics of the climate over a 30-yr time span using re-analysis air and remotely sensed sea surface temperatures. We then use feature-tracking techniques and manual digitisation of outlet glacier frontal positions on over 2000 satellite images covering the period from 1985 to 2011 to thoroughly sample outlet glacier behaviour around the ice sheet over the same time period.

Using both air and sea temperatures and a good spatial distribution of glaciers around the ice sheet, we aim to gain insight as to whether air or ocean temperatures are the dominant control on outlet glacier dynamics. The high number of coincident retrievals of ice speed and ice-front position also allows us to determine the strength of the relationship 
Table 1. Glacier outlet catchment areas, widths and locations for speed measurements (behind the most retreated frontal position). P-values are based on a Levene test for the null hypothesis that there is no difference in flow speed variance before and after 1995; values less than 0.1 are in bold. The correlation coefficient (CC) is that between speed and frontal position over the full time series. No CC for Kong Oscar or Nioghalvfjerdsbrae because fronts were not digitised for some or any of the velocity measurements.

\begin{tabular}{|c|c|c|c|c|c|c|c|}
\hline Glacier & $\begin{array}{c}\text { Area } \\
\left(\times 10^{4} \mathrm{~km}^{2}\right)\end{array}$ & $\begin{array}{l}\text { Width } \\
(\mathrm{km})\end{array}$ & $\begin{array}{l}\text { Map date } \\
\text { (Fig. 1) }\end{array}$ & $\begin{array}{c}\text { Measurement } \\
\text { location }\end{array}$ & $\begin{array}{c}\text { Mean speed } \\
\text { pre-1996 } \\
\left(\mathrm{md}^{-1}\right)\end{array}$ & P-value & $\mathrm{CC}$ \\
\hline Kangerdlugssuaq & $5.14(2.9 \%)$ & 7.8 & 16 Sep 1985 & $1.8 \mathrm{~km}$ & 13.2 & 0.0 & -0.80 \\
\hline Helheim & $5.19(3.0 \%)$ & 6.3 & 24 Jul 1992 & $0.9 \mathrm{~km}$ & 15.2 & 0.0 & -0.85 \\
\hline Ikertivaq A & $1.57(0.9 \%)$ & 4.1 & 26 Sep 1986 & $0.9 \mathrm{~km}$ & 9.7 & 0.09 & -0.79 \\
\hline Ikertivaq B & in & 2.3 & & $1.4 \mathrm{~km}$ & 7.5 & 0.07 & -0.76 \\
\hline Ikertivaq C & total & 2.4 & & $0.2 \mathrm{~km}$ & 9.8 & 0.19 & -0.59 \\
\hline Ikertivaq D & & 3.4 & & $0.3 \mathrm{~km}$ & 11.7 & 0.37 & -0.64 \\
\hline Ikertivaq E & & 2.5 & & $0.6 \mathrm{~km}$ & 17.8 & 0.22 & -0.87 \\
\hline Gyldenlove & $0.74(0.4 \%)$ & 2.7 & 18 Apr 1989 & $1.0 \mathrm{~km}$ & 10.5 & 0.46 & -0.52 \\
\hline Jakobshavn Isbræ & $8.88(5.1 \%)$ & 9.6 & 1 Apr 1989 & $1.4 \mathrm{~km}$ & 12.5 & 0.0 & -0.97 \\
\hline Ingia Isbræ & $3.32(1.9 \%)$ & 3.2 & 2 May 1987 & $0.7 \mathrm{~km}$ & 2.0 & 0.16 & -0.70 \\
\hline Umiamako & in & 3.5 & & $0.7 \mathrm{~km}$ & 1.8 & $\mathbf{0 . 0}$ & -0.92 \\
\hline Rink & total & 5.2 & & $0.9 \mathrm{~km}$ & 10.0 & 0.12 & -0.61 \\
\hline Kong Oscar & $2.69(1.5 \%)$ & 4.2 & 7 Aug 1985 & & 7.9 & 0.60 & \\
\hline Petermann & $7.40(4.2 \%)$ & 22.1 & 22 Jul 2006 & $44 \mathrm{~km}$ & 2.8 & 0.29 & -0.53 \\
\hline Nioghalvfjerdsbrae & $6.57(3.8 \%)$ & 21.5 & 26 May 1985 & & 3.1 & 0.77 & \\
\hline Daugaard-Jensen & $4.86(2.8 \%)$ & 4.6 & 3 Aug 1986 & $5.5 \mathrm{~km}$ & 8.4 & 0.95 & -0.17 \\
\hline
\end{tabular}

between retreat and acceleration by calculating the statistical correlation between the two parameters for each glacier in our study.

\subsection{Air and sea surface temperatures}

Gridded time series of monthly and summer mean air and sea surface temperatures covering Greenland and the surrounding ocean were analysed for the period 1982-2010. Global atmospheric reanalysis (ERA-Interim) monthly mean $2 \mathrm{~m}$ air temperature data, at a spatial resolution of $1.5^{\circ}$, were obtained from the European Centre for Medium-Range Weather Forecasts (ECMWF). The SSTs are based on Optimum Interpolation 1/4 Degree Daily Sea Surface Temperature Analysis (OISST), AVHRR-only data from the US National Climatic Data Center (Reynolds et al., 2007). Both sets of data were reprojected to a polar stereographic coordinate system.

Following suggestions that the switching of the NAO from a positive to a neutral state in the mid-1990s allowed Greenland temperatures to reflect Northern Hemisphere warming (Hanna et al., 2008), trend lines were fitted to the summer mean temperature grids, using a linear least squares regression for two periods: 1982-1995 and 1995-2010. In addition, total period summer means were calculated and the earlier period subtracted from the later.

\subsection{Flow speeds and frontal positions}

Time series of surface velocities and frontal positions were measured for 16 tidewater outlet glaciers in total. The sample avoided known surge-type glaciers and, where possible, included the largest glaciers discharging all sectors of the ice sheet. For the chosen glaciers, as many pairs as possible of high spatial resolution satellite images of all types were analysed within the restrictions imposed by archive contents and cloud cover.

The velocities were measured by applying feature tracking between pairs of optical (Landsat-5 TM Band 4 and Landsat7 ETM+ Band 8) and synthetic-aperture radar (ERS-1, ERS2 and Envisat (Advanced) SAR (ASAR)) images (Scambos et al., 1992; Lucchitta et al., 1995; Strozzi et al., 2002; Luckman et al., 2003; Pritchard et al., 2005). The optical pairs were separated by either 16 or $32 \mathrm{~d}$ and, before tracking, were resampled from $30 \mathrm{~m}$ to $20 \mathrm{~m}$ (TM) and from $15 \mathrm{~m}$ to $10 \mathrm{~m}$ $(\mathrm{ETM}+)$ and reprojected to the polar stereographic coordinate system. The SAR pairs were multi-looked at $1 \times 5$ to a ground pixel size of approximately $20 \mathrm{~m}$ and tracked in slant-range and azimuth geometry over $35 \mathrm{~d}$. A spatial sampling for the feature-tracking of $40 \mathrm{~m}$ was selected such that velocity fields were produced at $40 \mathrm{~m}$ resolution for all image types. Geocoding of Landsat-5 velocity fields was improved by co-registering the first image of the pair to a Landsat-7 image from the same track, and SAR image displacements were converted from slant-range and azimuth to surface-parallel 

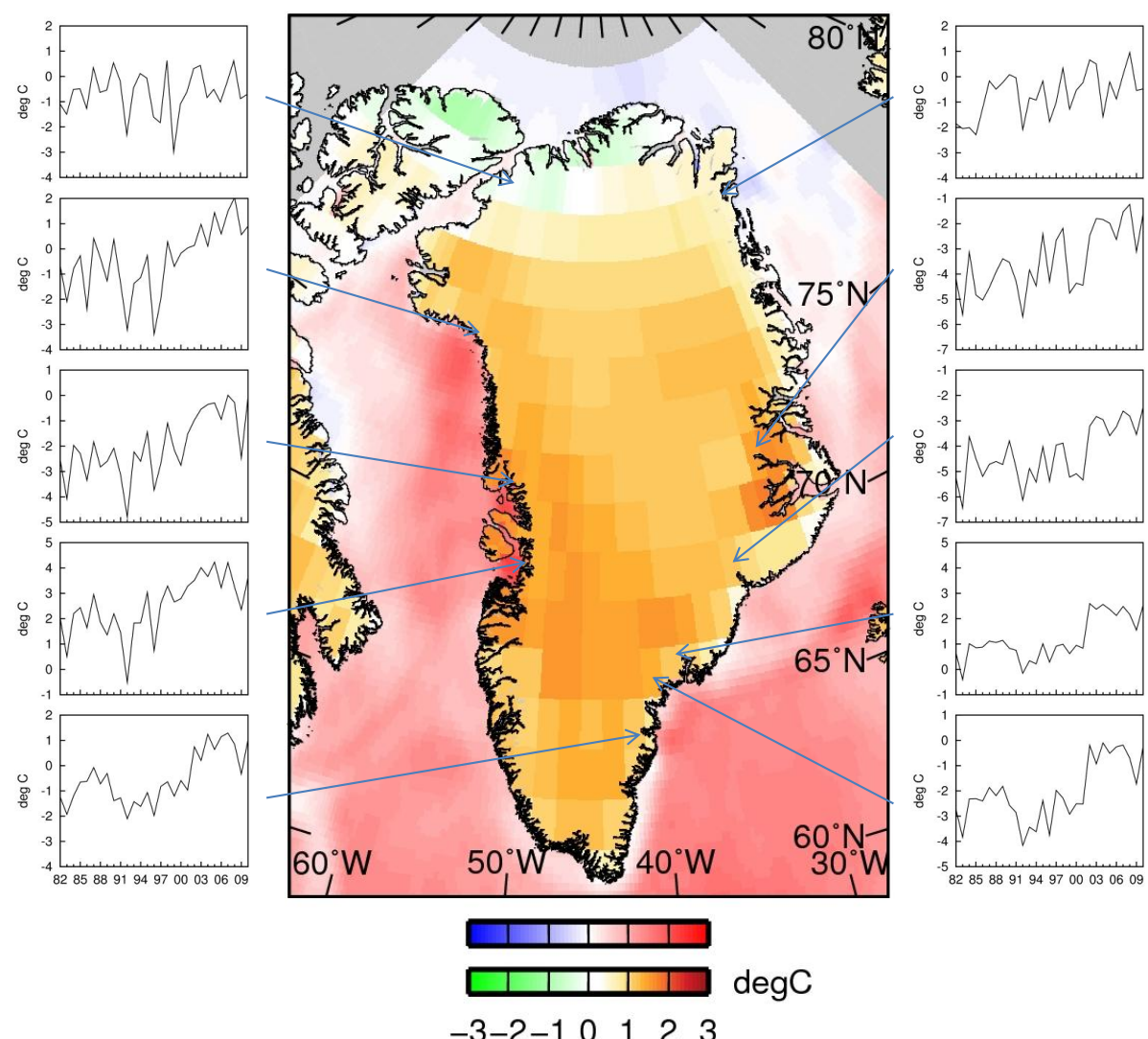

$-3-2-1 \quad 0 \quad 1 \quad 2 \quad 3$

Fig. 2. Difference in mean summer temperature between and 1996-2010 and 1982-1995. Over land: ERA-Interim summer (June-August) $2 \mathrm{~m}$ air temperature. Over ocean: OISST summer (July-September) sea surface temperature. The upper colour bar applies to the SSTs and the lower colour bar to the air temperatures. Surrounding plots show summer mean air temperatures from the ERA-Interim dataset for single pixels located over the lower few km of the indicated glacier catchments.

using orbit data and the ASTER global DEM (digital elevation model). The final velocity fields were then filtered with respect to expected downslope flow direction (Luckman et al., 2006).

The errors associated with determination of surface velocity using feature tracking include random errors associated with measuring the two-dimensional displacement of surface features, and systematic errors associated with reprojection and geolocation. Co-registration of patches with a precision of 1/10th (Gray et al., 2001) to 1/20th (Strozzi et al., 2002) of a pixel is possible. Hence, the errors associated with determining the displacements are, in the worst case, $\approx 0.2 \mathrm{md}^{-1}$ for tracking of Landsat 5 images over 16 days, and less for the other image pairs. Errors introduced during subsequent processing can be estimated by measuring the mean displacement over a stationary point close to the front of the glacier being tracked. Bevan et al. (2012) found the mean displacement at such points was $0.28 \mathrm{md}^{-1}$ for Landsat-5 images, $0.09 \mathrm{md}^{-1}$ for Landsat-7 images, and $0.22 \mathrm{md}^{-1}$ for SAR images. Combining the above errors as independent error sources results in a maximum estimated error of $0.34 \mathrm{md}^{-1}$.
Ice-front positions were manually digitised on each Landsat and SAR image including those unsuitable for feature tracking. The intersection points of the digitised fronts with a centreline profile were used as single-point indicators of ice-front position. Errors in ice-front location can arise as a result of geolocation error and also depend on the precision with which the fronts are digitised, which depends on image type and resolution. Bevan et al. (2012) found accuracies of $\pm 49 \mathrm{~m}$ for SAR images and $\pm 76 \mathrm{~m}$ for Landsat- 5 images; Landsat-7 images are likely to be more accurate. All time series of ice-front positions presented include some estimates based on Landsat-5, so the overall accuracy should be considered to be $\pm 76 \mathrm{~m}$.

\subsection{Basin outlines}

Catchment boundaries were delineated by tracing flowlines upstream from the glacier terminus following the method of Costa-Cabral and Burges (1994) (see Fig. 1). Flow directions were derived from smoothed fields of gravitational driving stress (GDS) (Le Brocq et al., 2006). The GDS fields were based on a digital elevation model and an ice thickness grid 

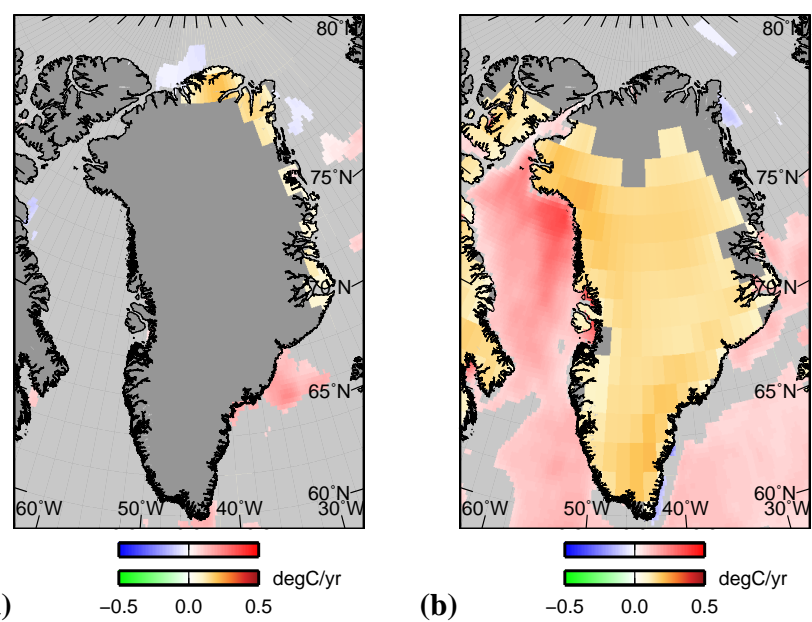

Fig. 3. Linear trend in temperature over the periods (a) 1982 to 1995 and (b) 1995 to 2010, where significant at the $95 \%$ level. Over land: ERA-Interim summer (June-August) mean $2 \mathrm{~m}$ air temperatures. Over ocean: OISST summer (July-September) sea surface temperatures. The upper colour bars apply to the SSTs and the lower colour bars to the air temperatures. Grey pixels are where the difference was not significant at the $95 \%$ level.

of $5 \mathrm{~km}$ resolution (Bamber et al., 2001), were computed at $1 \mathrm{~km}$ resolution, and were linearly smoothed over a distance equivalent to 20 times the ice thickness. The selection of start points at the glacier terminus was restricted to locations covered by the DEM and guided by visual inspection of the ice margins and velocity distribution. Catchment areas and their percentage of total ice-sheet area are listed in Table 1.

\section{Results}

\subsection{Air and sea surface temperatures}

The analyses of SSTs and re-analysis air temperatures show that the mean summer temperatures during the 1996-2010 period were warmer everywhere than in 1985-1995, apart from in the far north (Fig. 2). Over land, southern and coastal temperatures showed the greatest warming. Coastal SSTs showed little warming except in the north-west even though offshore SSTs were significantly higher in the later period. Summer mean air temperatures, extracted from the ERAInterim data for single-pixel locations on the lower few $\mathrm{km}$ of each glacier, are clearly increasing steadily from the mid1990s at all locations except for the far north over Petermann glacier (Fig. 2).

Between 1985 and 1995 no significant trends in air or sea surface temperatures were detected other than increases over a small patch of ocean between south-east Greenland and Iceland, and over the far north-west of Greenland (Fig. 3a). Between 1995 and 2010, however, linear increases in summer SST and air temperatures were widespread and sig- nificant (Fig. 3b). Trends in SST of up to $0.5^{\circ} \mathrm{C} \mathrm{yr}^{-1}$ occur off the west coast between 70 and $75^{\circ} \mathrm{N}$. The northwestern limit of SST warming is the northern tip of the Nares Strait (Fig. 1), where water at $300 \mathrm{~m}$ depth was also found to have warmed significantly during the period 2003-2009 (Münchow et al., 2011).

An exception to the widespread increases in SST is over the south-east and southern coastal shelf where there is either cooling or no significant warming (Fig. 2). This region coincides with the location of the East Greenland Current (EGC), a surface current that flows south along the shelf break and exports fresh, cold, polar surface water from the Arctic (Nilsson et al., 2008). The East Greenland Coastal Current (EGCC), which flows closer to shore south of the Denmark Strait (Fig. 1), also occupies this coastal region. Interannual variability in the composition of the EGC/EGCC is high; increases in the freshwater component in the late 1990s were attributed to increased Greenland glacial runoff, and in 2005 to an increase in sea-ice meltwater resulting from a peak in sea-ice export through the Fram Strait (Cox et al., 2010). This increase in freshwater may explain the cooling and/or lack of warming in surface waters on the shelf compared with further offshore.

\subsection{Frontal positions and velocities}

Time series of flow speeds and frontal positions are discussed in the following subsections, starting with Kangerdlugssuaq and other glaciers in the south-east and working clockwise around the ice sheet. In each case, flow speeds near the front were picked from the feature-tracking data at a location which maximised the number of possible retrievals through the observation period; the locations are marked on the velocity maps in Fig. 1. In the following discussions, we use the term stable to refer to ice fronts or speeds that are within the range of expected values up to that date. The range of expected values is somewhat qualitative but is based on an inspection of the record and a consideration of published seasonal variability and the likely error in observations.

\subsubsection{South-eastern glaciers}

This sector has experienced significant and accelerating mass loss over the last decade, and many outlet glaciers have accelerated and retreated (Walsh et al., 2012). Kangerdlugssuaq and Helheim glaciers together drain about $6 \%$ of the area of the GrIS; their calving fronts are both $80 \mathrm{~km}$ from their respective fjord mouths, and deep troughs of more than $500 \mathrm{~m}$ and $750 \mathrm{~m}$, respectively, connect the fjords to the shelf break (Murray et al., 2010). The two glaciers have attracted much attention because they account for a substantial portion of the regional mass loss (Howat et al., 2011) and were among the first to have been observed to have undergone change (Luckman et al., 2006). Rates of mass loss are now declining in the region (Schrama et al., 2011), and Kangerdlugssuaq and 


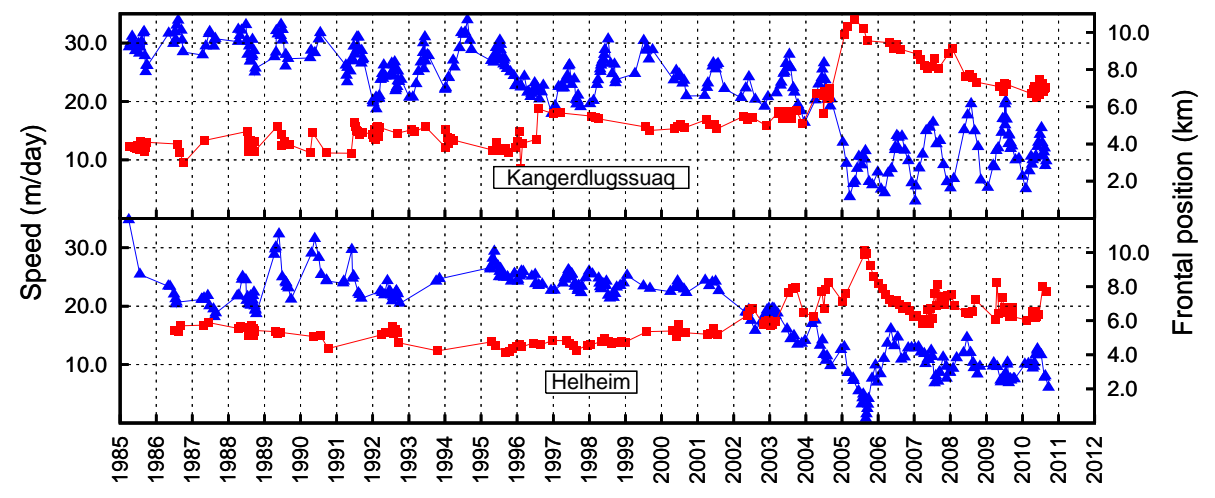

Fig. 4. Surface flow speeds (red squares) and frontal positions (blue triangles) for Kangerdlugssuaq and Helheim glaciers (see Fig. 1 for locations).

Helheim began to slow and re-advance in 2006 (Howat et al., 2007; Murray et al., 2010). Here (Fig. 4) we extend the published record of flow speeds back in time by all data points prior to 1992, i.e. $6 \mathrm{yr}$ for Kangerdlugssuaq and $7 \mathrm{yr}$ for Helheim. The temporal extent and sampling of ice-front positions are also improvements on the published record.

Although there is some evidence of interannual variability, the 25-yr record of surface speed and ice-front position (Fig. 4) reaffirms that the speed-ups in the mid-2000s were exceptional in the satellite record and were similar in timing and magnitude despite the $300 \mathrm{~km}$ separation between glaciers. Prior to retreat and acceleration, Helheim is shown to be stable for at least $16 \mathrm{yr}$. Similarly, Kangerdlugssuaq is known to have been flowing at similar speeds in 1966, 1988 and 1995/96 (Csatho et al., 1999; Thomas et al., 2000), and our data confirm the stability between 1985 and 1996.

The ice-front and speed records also exhibit two major differences between this pair of glaciers (Fig. 4). First, there is a contrast in the timing of the response to the mid-2000s event. Helheim seems to begin its period of retreat and speedup from 2002, a response which accelerated to a maximum in 2005, while Kangerdlugssuaq underwent a simple stepchange between 2004 and 2005. Second, bearing in mind that the temporal sampling in some years is poor, the seasonal fluctuation in ice-front position is generally more pronounced for Kangerdlugssuaq than for Helheim. Kangerdlugssuaq's ice front is normally seen to advance to a maximum in the middle of the calendar year, and retreat to a minimum at the end of December or in early January. There are only two exceptions to this pattern in the long-term record: the first in 1995/96 coincided with a increase in speed of about $6 \mathrm{md}^{-1}$; the second in 2004/05 coincided with the well-known larger speed-up. In these two cases, the atypical behaviour is characterised by an unusually long phase of retreat into February or March and an increase in surface speed which was much more pronounced in the 2004/05 event than in the earlier one (1995/96) (Fig. 4).
The Ikertivaq glaciers A to E are a series of outlet glaciers draining the catchment immediately south of Helheim and are labelled north to south. These outlets discharge into a bay rather than a fjord. Only outlet D shows no sign of the acceleration between 2000 and 2005 (Fig. 5) characteristic of the south-east region (Rignot and Kanagaratnam, 2006; Howat et al., 2008). Between 1986 and 2000, none of the 5 outlets show any signs of significant flow change other than that which could be attributed to seasonal velocity variations. All except $\mathrm{B}$ exhibit intra-annual changes in frontal position of the order of $1 \mathrm{~km}$, and after $2000 \mathrm{~A}, \mathrm{C}$ and E begin retreats of 1.5 to $2 \mathrm{~km}$ over a period of $8 \mathrm{yr}$ coincident with acceleration, with only E appearing to have stabilised by 2011 .

Gyldenlove glacier is one of three glaciers discharging into a single fjord, and is $50 \mathrm{~km}$ from the fjord mouth; another one discharges at a similar rate; the other is less active. A deep trough exists between the fjord mouth and the shelf break (Murray et al., 2010). From 1985 until 1998, flow speeds show intra-annual variability of $\pm 1 \mathrm{md}^{-1}$, but no overall change. The ice front advances by at least $2.6 \mathrm{~km}$ in 1985 and then retreats by $3.9 \mathrm{~km}$ by 1986 , with a $1.3 \mathrm{~km}$ advance and retreat in 1989 to 1990 . The front then remains at a more retreated position for the remainder of the record. From 1998 onwards this glacier appears to follow a typical southeastern outlet glacier cycle of acceleration and retreat followed by deceleration from 2004, although with no sign of a readvance (Fig. 5).

\subsubsection{Western glaciers}

Measurements of flow speed and frontal position for Jakobshavn Isbræ are presented for a point $1.4 \mathrm{~km}$ behind the most retreated frontal position (Fig. 1). Measurements for various locations on this glacier have been published for most of this time series (Joughin et al., 2004; Luckman and Murray, 2005; Joughin et al., 2008; Motyka et al., 2011; Howat et al., 2011), and new data here are limited to the 1989, 1992 and 2011 data points (Fig. 6). 


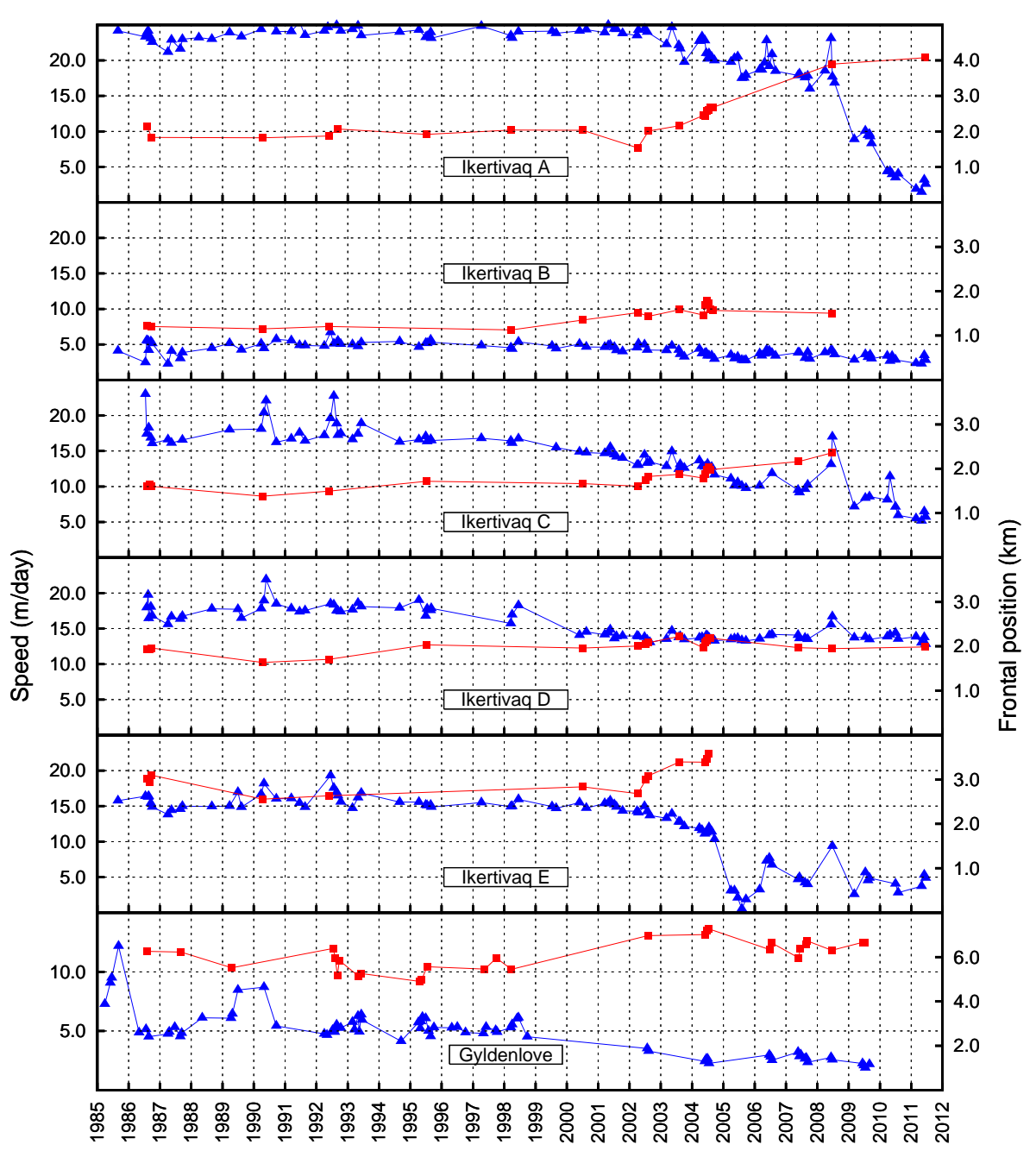

Fig. 5. Surface flow speeds (red squares) and frontal positions (blue triangles) for the Ikertivaq and Gyldenlove glaciers (see Fig. 1 for locations).

Flowing at over $25 \mathrm{md}^{-1}$, Jakobshavn Isbræ was the fastest flowing outlet glacier of the GrIS in 2011, and drains about $5 \%$ of the ice sheet. Its calving front is currently located almost $50 \mathrm{~km}$ up a long narrow fjord; the fjord is connected to the shelf break via a deep ( $>400 \mathrm{~m}$ ) trough (Holland et al., 2008). After retreating from its 1850 Little Ice Age maximum extent, with periods of rapid thinning between 1902 and 1913 and between 1930 and 1959 (Csatho et al., 2008), it remained stable and in equilibrium until 1997 (Joughin et al., 2008; Motyka et al., 2011), even thickening sporadically between 1993 and 1998 (Thomas et al., 2003). In 1998 Jakobshavn Isbræ began a multi-year period of retreat and acceleration (Joughin et al., 2004; Rignot and Kanagaratnam, 2006; Motyka et al., 2011), during which speeds near the front doubled and the ice shelf disintegrated. Between 2000 and 2010, 321 \pm 12 Gt of grounded ice mass were lost (Howat et al., 2011). Seasonal velocity variations over the first $30 \mathrm{~km}$ upstream of the grounding line have been de- tected only since 1995 (Luckman and Murray, 2005) and appear to be driven by fluctuations in ice-front position rather than by seasonal melt input (Joughin et al., 2008). The amplitude of these oscillations increased from an initial $10 \%$ to almost $50 \%$ by 2009 (Howat et al., 2011). Seasonal fluctuations in ice-front position of 5-10 km are not uncommon.

Joughin et al. (2004) reported a slow down of the order of $15 \%$ in mean velocity between 1985 and 1992, followed by stable flow speeds until 1997 . We see no evidence of a slow down over this period, including a measurement made in 1989, and suggest that the results of Joughin et al. (2004) may have been a result of sampling seasonal variations (Luckman and Murray, 2005). The 1985 measurement by Joughin et al. (2004) related to July and the 1992 speed was a temporal average based on feature-tracking of five SAR pairs. The glacier now appears to be recovering from maximum flow speeds reached in 2009 and 2010 and in 2011 has slowed by approximately $5 \mathrm{md}^{-1}$, and the front has 


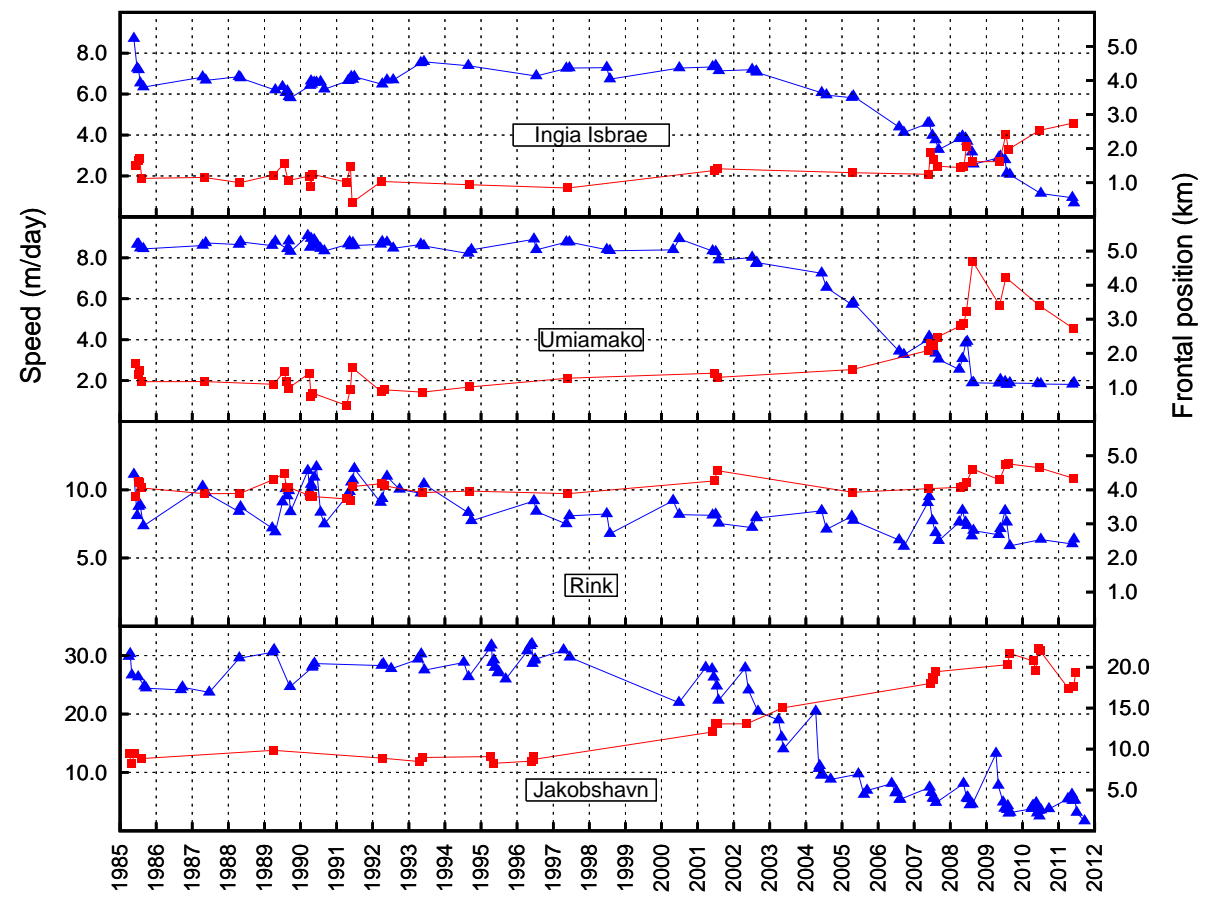

Fig. 6. Surface flow speeds (red squares) and frontal positions (blue triangles) for the Umiamako, Ingia Isbræ, Rink Isbræ and Jakobshavn Isbræ glaciers (see Fig. 1 for locations).

begun to stabilise. This slowdown is unexpected; rapid velocity increases have been predicted until 2015 on the basis of continued thinning in conjunction with retreat of the grounding line over a bed that deepens further inland (Thomas et al., 2011).

Rink Isbræ, Ingia Isbræ and Umiamako (Fig. 1) are located in a region where, between 2000 and 2009, coincident periods of retreat, thinning and acceleration were common but not in a manner that was synchronous between glaciers (McFadden et al., 2011). All three glaciers calve into narrow fjords which then together connect to Baffin Bay via a 60$\mathrm{km}$-wide channel.

Rink Isbræ is the southernmost of this set of glaciers and exhibits a strong seasonal variation in frontal position and speed, with retreat correlated with speed (Howat et al., 2010). Unusually for the region it displayed no overall speed-up between 2000 and 2005 (Rignot and Kanagaratnam, 2006; Joughin et al., 2010), and no speed up or surface elevation change between 2000 and 2009 (McFadden et al., 2011). Allowing for reported seasonal speed variations of up to $25 \%$ (Howat et al., 2010), it can be seen that the speed is also stable between 1985 and 2002 (Fig. 6). Frontal positions show some interannual change greater than the previously reported $\pm 500 \mathrm{~m}$ seasonal variation, with an overall retreat in mean position of about $1 \mathrm{~km}$ over $25 \mathrm{yr}$.

Further north, Umiamako also shows stable speeds and frontal positions from 1985 (Fig. 6) until the dramatic retreat beginning around 2003 and acceleration from 2005 reported by McFadden et al. (2011). From 2008 the glacier begins to slow but does not readvance, and in 2011 still flows faster than pre-retreat speeds.

Ingia Isbræ (Fig. 6) follows a similar pattern to Umiamako, no significant change in front or speed until retreat and a more gradual acceleration beginning at the same time as Umiamako (Howat et al., 2010) but with no sign of stabilization by 2011.

Kong Oscar glacier (Fig. 1) was reported to have sped-up by $12 \%$ between 1996 and 2000 and then to have remained stable until 2005 (Rignot and Kanagaratnam, 2006). However, as can be seen from Fig. 7, speeds overall remain remarkably constant between 1985 and 2006. Prior to 2002 the ice front was approximately $5-10 \mathrm{~km}$ beyond the mouth of the fjord and difficult to digitise precisely. From 2002 the front retreated $3 \mathrm{~km}$ over the next $5 \mathrm{yr}$, and McFadden et al. (2011) report that it thinned by $15 \mathrm{~m}$ during this period. After 2008 the ice front becomes stable with signs of a readvance by 2010 .

\subsubsection{Northern glaciers}

The northern sector of the GrIS, including the Petermann and Nioghalvfjerdsbrae glaciers, was thinning along the coast in the periods 1994-1999 (Krabill et al., 2000) and 1997-2003 (Krabill et al., 2004), and glacier fronts and grounding lines were retreating between 1992 and 1996 (Rignot et al., 2001). Although it was speculated that the change must be dynamic in origin, little change in flow speeds was detected on Petermann at intervals between 1991 and 2005/06 (Joughin 


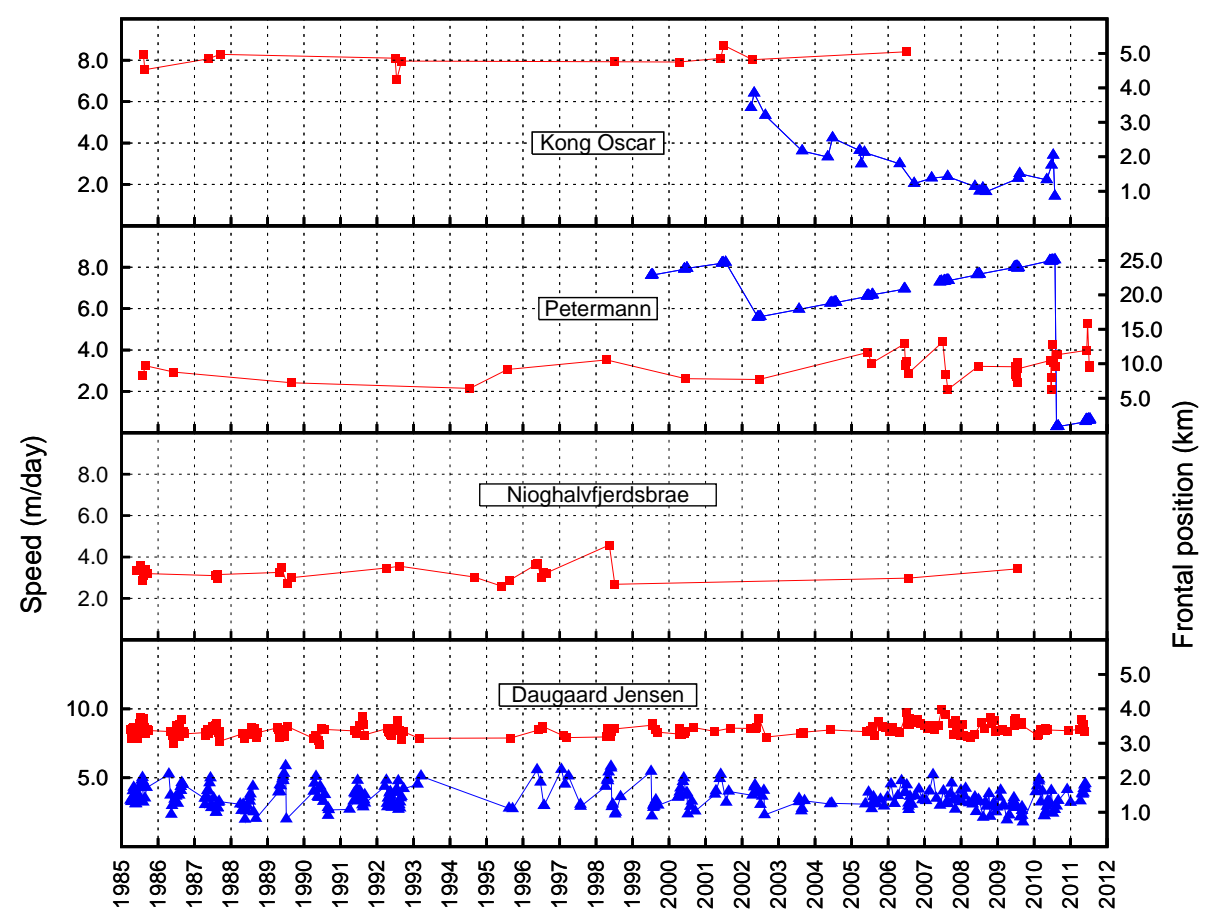

Fig. 7. Surface flow speeds (red squares) and frontal positions (blue triangles) for the Kong Oscar, Petermann, Nioghalvfjerdsbrae and Daugaard-Jensen glaciers (see Fig. 1 for locations).

et al., 1999, 2010) and a small deceleration was reported on Nioghalvfjerdsbrae 1996 to 2000 and 2000 to 2005 (Rignot and Kanagaratnam, 2006). Allowing for seasonal variations, the time series (Fig. 7) suggests that Petermann glacier flow speeds were stable from 1985 until 2011, despite a major calving event in 2010 (Nick et al., 2012), although the highest velocities are in the most recent years. The latter Nioghalvfjerdsbrae deceleration (Rignot and Kanagaratnam, 2006) is not apparent in our time series in Fig. 7, but we do see an acceleration between 1995 and 1998, followed by an immediate deceleration. Taken together with the observations of Rignot and Kanagaratnam (2006), it appears that there was some disturbance to the flow of the glacier in the period between 1995 and 2000.

Petermann glacier has a floating tongue that is approximately $70 \mathrm{~km}$ long with a grounding line that is approximately $85 \mathrm{~km}$ from the fjord entrance. The width of the fjord varies between 15 and $20 \mathrm{~km}$, is $1100 \mathrm{~m}$ deep, and is separated from Hall Basin by a sill at a depth of approximately $350 \mathrm{~m}$ to $450 \mathrm{~m}$ (Johnson et al., 2011). Ice-front positions presented here for Petermann add to the long time series presented by Falkner et al. (2011) dating back to 1876, and Johannessen et al. (2011) from 1953. Within the time span of our flow speed record, Johannessen et al. (2011) observed large calving events in 1991 and 2001 in addition to the 2010 event. A further large calving event took place on 16/17 July 2012 leaving the ice front approximately $5.3 \mathrm{~km}$ further retreated than the last position plotted in Fig. 7. This estimate is based on a MODIS (Moderate Resolution Imaging Spectroradiometer) image for 17 July 2012 downloaded from the NASA website (http://visibleearth.nasa.gov/) which has a spatial resolution of $250 \mathrm{~m}$.

Nioghalvfjerdsbrae terminates in a floating ice shelf which flows east to a $35 \mathrm{~km}$ calving front and north-east to a 10$\mathrm{km}$-wide front. An overdeepened trough of $900 \mathrm{~m}$ exists under the ice shelf with bathymetry rising to $200 \mathrm{~m}$ and $600 \mathrm{~m}$ beneath the east and north-east fronts, respectively (Mayer et al., 2000). A complete analysis of Nioghalvfjerdsbrae frontal positions is not included as the complex shape of the calving zone and the almost permanent fjord ice make it difficult to confidently identify the ice front. Nioghalvfjerdsbrae is known to experience calving events on timescales of decades with a large calving event from the east front in 1997, the first since 1963, following the break-up of the seaward fast ice (Reeh et al., 2001). We identify no other major event apart from a break-up and retreat of the north branch between July 2006 and August 2007 with the loss of approximately $36 \mathrm{~km}^{2}$ of floating ice.

Lastly, Daugaard-Jensen glacier, which drains an estimated $4 \%$ of the Greenland ice sheet, has a short floating tongue of approximately $6 \mathrm{~km}$, and discharges into the northwest corner of the Scoresby Sund fjord system in east Greenland. Daugaard-Jensen glacier is included with the northern glaciers as it is known to be exhibiting unusual stability more akin to the northern glaciers than the southeastern glaciers and it may have a short floating tongue (Rignot et al., 2004; 
Stearns et al., 2005; Bevan et al., 2012). Our 1985 to 2011 record of flow speeds and frontal positions for this glacier (Fig. 7) repeats that presented in Bevan et al. (2012) and is included here to allow comparison with other glaciers. The record shows that Daugaard-Jensen has maintained stable flow speeds and frontal position throughout the period 19852010; current velocities and ice-front position match those of 1968 (Stearns et al., 2005). Daugaard-Jensen is typical of other glaciers in this region, north of $69^{\circ} \mathrm{N}$, which exhibited little inter-annual variability in flow or ice-front position between 2000 and 2010 (Walsh et al., 2012).

\section{Discussion}

Flow speeds for all glaciers shown were stable throughout the first $10 \mathrm{yr}$ of the $25 \mathrm{yr}$ time series of measurements. The stability is also clearly apparent in ice-front positions after allowing for the seasonal advance and retreat pattern common to many glaciers. For a number of glaciers, the summer advance is not detected every year, e.g. Helheim, and Ikertivaq C, D and E. On Gyldenlove an advance occurs only in 1985 and in 1989 to 1990, and not again for the remainder of the record.

This $10-y r$ period of stability in ice front and speed greatly emphasises the exceptional subsequent behaviour of those glaciers which, according to our work and previous studies, experience and respond to changes in climate. During the following $15 \mathrm{yr}$, as detected in many other studies, tidewater glaciers in the south-east and west both accelerated and retreated. The exceptions observed here are Rink Isbræ in the west, which does not seem to accelerate and retreats only slightly, and Ikertivaq D in the south-east, which appears to be fairly stable both in flow speed and ice-front position. Both the Ikertivaq outlet and Rink Isbræ are exposed to the same temperature regimes as other glaciers in the immediate vicinity that do experience retreat, and we presume unknown features in bed geometry may be stabilising these outlets. We also note that Kong Oscar exhibits similar behaviour to Ingia Isbræ, Umiamako and Jakobshavn Isbræ in terms of frontal retreat/loss of floating tongue; however, unusually there is no detectable impact here on flow speeds, although we only have measurements in 2002 and 2006. Prior to 2002 Kong Oscar ice front existed as a semi-coherent $5-10 \mathrm{~km}$ floating tongue extending beyond the coast as a conglomeration of partly connected tabular icebergs. Between 2002 and 2006 the front retreated to a well-defined, presumably grounded, linear ice front, and by 2006 was producing much narrower icebergs. The lack of detected acceleration was presumably because the loss of floating ice did not affect the stress balance as the ice removed was not bounded by fjord walls.

Elsewhere, glaciers exhibiting little sign of increased instability during the last $15 \mathrm{yr}$ are Petermann glacier and Nioghalvfjerdsbrae in the north, and Daugaard-Jensen in the east. The first two both experience sporadic major calving events (Reeh et al., 2001; Falkner et al., 2011; Johannessen et al., 2011), but there is no evidence of these events having any lasting effect on flow speeds, at least on Petermann (Nick et al., 2012). It is possible that the short-term acceleration on Nioghalvfjerdsbrae between 1995 and 1998 was associated with the 1997 calving event. Daugaard-Jensen has remained stable (Bevan et al., 2012) in spite of observed thinning (Pritchard et al., 2009) and mass losses for the region (Wouters et al., 2008; Schrama and Wouters, 2011).

The time series (Figs. 4 to 7) show that, for a subset of glaciers analysed, the last $15 \mathrm{yr}$ of the period for which we have velocities are characterised by an increase in the variability of the flow speeds, as well as the well-publicised speed ups. In order to measure the significance of this increase, a Levene test (Levene, 1960) was chosen to test the null hypothesis that the variances before and after 1995 are equal, as it does not require the underlying data to be normally distributed. All speed measurements were included apart from those based on SAR tracking, as these are measurable all year round and would have disproportionately emphasised the seasonal signal in the post- 1995 period. The $\mathrm{p}-$ values for the null hypothesis are listed in Table 1; a low p-value indicates a low probability that there is no change in variance; $p$-values less than or equal to 0.10 are in bold. For glaciers in the south-east and west, the variance in speed increased significantly after 1995 . This finding could be the result of an increase in the amplitude of the seasonal signal (e.g. Umiamako (Howat et al., 2010)), of change occurring over a multi-annual timescale (e.g. Helheim), or a combination of these causes. It should be noted that temporal sampling is variable both in time and between glaciers and that this may influence the p-value; the statistic should be viewed in conjunction with the time series plots.

The increase in flow-speed variance after 1995 for most western glaciers coincides with increases in both nearby summer mean air and sea surface temperatures. In the southeast, local air temperatures were increasing but SSTs adjacent to the coast were not. Noting that SSTs here may not be representative of temperatures at depth due to the surface currents, it may be more appropriate to consider the warming SSTs over the Irminger Sea as an indicator of the subsurface waters controlling submarine melt of the glacier fronts in this region (Straneo et al., 2010; Murray et al., 2010; Andresen et al., 2012).

In contrast, the stable northern glaciers of Petermann and Nioghalvfjerdsbrae, with high p-values, are in contact with the ocean in regions where SSTs have cooled extensively, even offshore. Daugaard-Jensen has also remained remarkably stable in spite of its more southerly location and increased summer air temperatures (Fig. 2). This stability may be a reflection of the fjord bathymetry or remoteness from the ocean hindering warm water access to the front, or due to the restricted latitudinal extent of recent changes in North Atlantic circulation. These circulation changes are thought to bring warm subtropical waters to the Irminger Sea and onto 
the continental shelf of south-east Greenland (Seale et al., 2011; Walsh et al., 2012).

In order to test the strength of the relationship between icefront position and speed, we calculated the Pearson's correlation coefficient between the two. Kong Oscar and Nioghalvfjerdsbrae were excluded from this analysis as there were few or no simultaneous measurements between the two parameters. The correlations are inverse and significant at the $99 \%$ level for all glaciers tested except for Ikertivaq C, Petermann and Daugaard-Jensen which are significant at $95 \%$ (Table 1). The correlations indicate either an interdependence between retreat and acceleration, consistent with the idea that a loss of resistive stress through ice-front retreat causes speed-up, or a mutual response to an external forcing. Glaciers with a weaker correlation either show little change in either parameter such as Daugaard-Jensen, or show advances or retreats in frontal position not accompanied by velocity changes, such as Petermann and Gyldenlove. On Petermann it has been shown that resistive stresses near the terminus region are too small relative to the driving forces to have a significant effect on flow speed (Nick et al., 2012). By comparison with Petermann, we propose that the ice front advances and retreats on Gyldenlove, and on Kong Oscar (where there were insufficient velocity measurements to derive a correlation coefficient), were also a result of the formation or loss of all or part of a floating tongue. For both these glaciers, the proposed floating tongues would be about $3 \mathrm{~km}$ long.

\section{Conclusions}

From 1985 to 1995 , during a climatically stable period of the 20th century for Greenland, Kangerdlugssuaq, Helheim, Jakobshavn Isbræ and 13 other major tidewater glaciers around the ice sheet maintained constant flow speeds and stable ice-front positions. Following this period, during 1995 to 2010 , there were widespread increasing trends in summer mean air and sea surface temperatures; this later period was warmer on average in the summer than the earlier period everywhere except in the far north. During the later period, there was a significant increase in the variance of flow speed for many glaciers, caused mostly by multi-year accelerations as, for example, on Kangerdlugssuaq, Helheim and Jakobshavn Isbræ glaciers. In some instances, the increase in variance was due to an increase in seasonal flow variability (e.g. Umiamako glacier) and sometimes a combination of this and multi-year accelerations. All glaciers showing a significant increase in flow-speed variance also showed a strong linear correlation between retreat and acceleration.

The major exceptions to these responses were Kong Oscar, Petermann, Nioghalvfjerdsbrae and Daugaard-Jensen glaciers which showed neither acceleration nor any observable increase in seasonality. We speculate that these glaciers were either not in a region of combined atmospheric and oceanic warming (Petermann and Nioghalvfjerdsbrae), or had a geometry such that retreat probably did not alter the stress balance at the ice front (Kong Oscar), or were remote from ocean warming influences even though atmospheric temperatures over land were increasing (Daugaard-Jensen).

The data presented here support the concept that, under conditions of increasing atmospheric and/or oceanic temperatures, the loss of floating tongues or retreat of grounded ice fronts changes the balance of forces at the termini of tidewater glaciers resulting in rapid glacier acceleration and thinning. The mechanism allows a rapid response to climate change, with individual fjord and bed geometries mediating that response. On the basis of the data studied here, heat delivery by the oceans is a prerequisite for acceleration and retreat of tidewater glaciers, but we cannot rule out the requirement for concomitant increases in air temperature. With annual average temperatures for Greenland predicted to warm by in excess of $3^{\circ} \mathrm{C}$ by 2100 (Gregory et al., 2004), and subsurface (200-500 $\mathrm{m}$ depth) oceans surrounding the ice sheet predicted to warm by $1.7-2.0^{\circ} \mathrm{C}$ over the same period (Yin et al., 2011) - a figure twice the global mean value - the results of our study suggest that acceleration and retreat of Greenland's tidewater glaciers is likely to continue whilst they remain in contact with the ocean.

Acknowledgements. Thanks to ESA for supplying ERS and Envisat SAR data, funded by NERC grant NE/G010366/1 and also under ESA project AOCRY2676, and to Mark Drinkwater at ESA for facilitating access to the Landsat archive. Landsat images were also downloaded from the US Geological Survey's Earth Explorer website. SLB is funded through GLIMPSE, a Leverhulme Trust Research Leadership Scheme project (F/00391/J). We acknowledge the support of the Climate Change Consortium of Wales. Thanks to reviewers S. Price and F. Nick for their helpful comments.

Edited by: S. Marshall

\section{References}

Amundson, J. M., Fahnestock, M., Truffer, M., Brown, J., Lüthi, M. P., and Motyka, R. J.: Ice mélange dynamics and implications for terminus stability, Jakobshavn Isbræ, Greenland, J. Geophys. Res., 115, F01005, doi:10.1029/2009JF001405, 2010.

Andersen, M. L., Larsen, T. B., Nettles, M., Elosegui, P., van As, D., Hamilton, G. S., Stearns, L. A., Davis, J. L., Ahlstrøm, A. P., de Juan, J., Ekström, G., Stenseng, L., Khan, S. A., Forsberg, R., and Dahl-Jensen, D.: Spatial and temporal melt variability at Helheim Glacier, East Greenland, and its effect on ice dynamics, J. Geophys. Res., 115, F04041, doi:10.1029/2010JF001760, 2010.

Andresen, C. S., Straneo, F., Ribergaard, M. H., Bjork, A. A., Andersen, T. J., Kuijpers, A., Norgaard-Pedersen, N., Kjaer, K. H., Schjoth, F., Weckstrom, K., and Ahlstrom, A. P.: Rapid response of Helheim Glacier in Greenland to climate variability over 
the past century, Nat. Geosci., 5, 37-41, doi:10.1038/ngeo1349, 2012.

Bamber, J. L., Layberry, R. L., and Gogineni, S. P.: A new ice thickness and bed data set for the Greenland Ice Sheet 1. Measurement, data reduction, and errors, J. Geophys. Res., 106, 33773 33780, doi:10.1029/2001JD900054, 2001.

Benn, D. I., Warren, C. R., and Mottram, R. H.: Calving processes and the dynamics of calving glaciers, Earth-Science Rev., 82, 143-179, doi:10.1016/j.earscirev.2007.02.002, 2007.

Bevan, S. L., Murray, T., Luckman, A. J., Hanna, E., and Huybrechts, P.: Stable dynamics in a Greenland tidewater glacier over 26 years despite reported thinning, Ann. Glaciol., 53, doi:10.3189/2102AoG60A076, 2012.

Bjørk, A. A., Kjær, K. H., Korsgaard, N. J., Khan, S. A., Kjeldsen, K. K., Andresen, C. S., Box, J. E., Larsen, N. K., and Funder, S.: An aerial view of 80 years of climate-related glacier fluctuations in southeast Greenland, Nat. Geosci., 5, 427-432, doi:10.1038/ngeo1481, 2012.

Box, J. E., Yang, L., Bromwich, D. H., and Bai, L.-S.: Greenland Ice Sheet surface air temperature variability: 1840-2007, J. Climate, 22, 4029-4049, doi:10.1175/2009JCLI2816.1, 2009.

Chen, J. L., Wilson, C. R., and Tapley, B. D.: Satellite gravity measurements confirm accelerated melting of Greenland Ice Sheet, Science, 313, 1958-1960, doi:10.1126/science.1129007, 2006.

Christoffersen, P., Mugford, R. I., Heywood, K. J., Joughin, I., Dowdeswell, J. A., Syvitski, J. P. M., Luckman, A., and Benham, T. J.: Warming of waters in an East Greenland fjord prior to glacier retreat: mechanisms and connection to large-scale atmospheric conditions, The Cryosphere, 5, 701-714, doi:10.5194/tc5-701-2011, 2011.

Costa-Cabral, M. C. and Burges, S. J.: Digital elevation model networks (DEMON): a model of flow over hillslopes for computation of contributing and disperal areas, Water Resour. Res., 30, 1681-1692, 1994.

Cox, K. A., Stanford, J. D., McVicar, A. J., Rohling, E. J., Heywood, K. J., Bacon, S., Bolshaw, M., Dodd, P. A., la Rosa, D., and Wilkinson, D.: Interannual variability of Arctic sea ice export into the East Greenland Current, J. Geophys. Res., 115, C12063, doi:10.1029/2010JC006227, 2010.

Csatho, B. M., Bolzan, J. F., van der Veen, C. J., Schenk, A. F., and Lee, D. C.: Surface velocities of a Greenland outlet glacier from high-resolution visible satellite imagery, Polar Geography, 23, 71-82, 1999.

Csatho, B., Schenk, T., van der Veen, C. J., and Krabill, W. B.: Intermittent thinning of Jakobshavn Isbrae, West Greenland, since the Little Ice Age, J. Glaciol., 54, 131-144, doi:10.3189/002214308784409035, 2008.

Falkner, K. K., Melling, H., Münchow, A. M., Box, J. E., Wohlleben, T., Johnson, H. L., Gudmandsen, P., Samelson, R., Copland, L., Steffen, K., Rignot, E., and Higgins, A. K.: Context for the recent massive Petermann Glacier calving event, EOS T. Am. Geophys. Un., 92, 117-124, doi:10.1029/2011EO140001, 2011.

Gray, A. L., Short, N., Mattar, K. E., and Jezek, K. C.: Velocities and flux of the Filchner ice shelf and its tributaries determined from speckle tracking interferometry, Can. J. Remote Sens., 27, 193-206, 2001.

Gregory, J. M., Huybrechts, P., and Raper, S. C. B.: Climatology: threatened loss of the Greenland ice-sheet, Nature, 428, 616, doi:10.1038/428616a, 2004

Hanna, E. and Cappelen, J.: Recent cooling in coastal Southern Greenland and relation with the North Atlantic Oscillation, Geophys. Res. Lett., 30, 1132, doi:10.1029/2002GL015797, 2003.

Hanna, E., Huybrechts, P., Steffen, K., Cappelen, J., Huff, R., Shuman, C., Irvine-Fynn, T., Wise, S., and Griffiths, M.: Increased runoff from melt from the Greenland Ice Sheet: a response to global warming, J. Climate, 21, 331-341, doi:10.1175/2007JCLI1964.1, 2008

Hanna, E., Cappelen, J., Fettweis, X., Huybrechts, P., Luckman, A., and Ribergaard, M. H.: Hydrologic response of the Greenland Ice Sheet: the role of oceanographic warming, Hydrol. Process., 23, 7-30, doi:10.1002/hyp.7090, 2009.

Hanna, E., Huybrechts, P., Cappelen, J., Steffen, K., Bales, R. C., Burgess, E., McConnell, J. R., Steffensen, J. P., van den Broeke, M., Wake, L., Bigg, G., Griffiths, M., and Savas, D.: Greenland Ice Sheet surface mass balance 1870 to 2010 based on twentieth century reanalysis, and links with global climate forcing, J. Geophys. Res., 116, D24121, doi:10.1029/2011JD016387, 2011.

Holland, D. M., Thomas, R. H., de Young, B., Ribergaard, M. H., and Lyberth, B.: Acceleration of Jakobshavn Isbræ triggered by warm subsurface ocean waters, Nat. Geosci., 1, 659-664, doi:10.1038/ngeo316, 2008 .

Howat, I. M. and Eddy, A.: Multi-decadal retreat of Greenland's marine-terminating glaciers, J. Glaciol., 57, 389-396, doi:10.3189/002214311796905631, 2011.

Howat, I. M., Joughin, I., Tulaczyk, S., and Gogineni, S.: Rapid retreat and acceleration of Helheim Glacier, East Greenland, Geophys. Res. Lett., 32, L22502, doi:10.1029/2005GL024737, 2005.

Howat, I. M., Joughin, I., and Scambos, T. A.: Rapid changes in ice discharge from Greenland outlet glaciers, Science, 315, 15591561, doi:10.1126/science.1138478, 2007.

Howat, I. M., Joughin, I., Fahnestock, M., Smith, B. E., and Scambos, T. A.: Synchronous retreat and acceleration of Southeast Greenland outlet glaciers 2000-06: ice dynamics and coupling to climate, J. Glaciol., 54, 646-660, doi:10.3189/002214308786570908, 2008.

Howat, I. M., Box, J. E., Ahn, Y., Herrington, A., and McFadden, E. M.: Seasonal variability in the dynamics of marineterminating outlet glaciers in Greenland, J. Glaciol., 56, 601613, doi:10.3189/002214310793146232, 2010.

Howat, I. M., Ahn, Y., Joughin, I., van den Broeke, M. R., Lenaerts, J. T. M., and Smith, B.: Mass balance of Greenland's three largest outlet glaciers, 2000-2010, Geophys. Res. Lett., 38, L12501, doi:10.1029/2011GL047565, 2011.

Jakobsson, M., Macnab, R., Mayer, L., Anderson, R., Edwards, M., Hatzky, J., Schenke, H. W., and Johnson, P.: An improved bathymetric portrayal of the Arctic Ocean: implications for ocean modeling and geological, geophysical and oceanographic analyses, Geophys. Res. Lett., 35, L07602, doi:10.1029/2008GL033520, 2008.

Johannessen, O. M., Babiker, M., and Miles, M. W.: Petermann Glacier, North Greenland: massive calving in 2010 and the past half century, The Cryosphere Discuss., 5, 169-181, doi:10.5194/tcd-5-169-2011, 2011

Johnson, H. L., Münchow, A., Falkner, K. K., and Melling, H.: Ocean circulation and properties in Petermann Fjord, Greenland, J. Geophys. Res., 116, C01003, doi:10.1029/2010JC006519, 
2011.

Joughin, I. R., Fahnestock, M. A., Kwok, R., Gogineni, P., and Allen, C.: Ice flow of Humboldt, Petermann and Ryder Gletscher, Northern Greenland, J. Glaciol., 45, 231-241, 1999.

Joughin, I., Abdalati, W., and Fahnestock, M.: Large fluctuations in speed on Greenland's Jakobshavn Isbrae glacier, Nature, 432, 608-610, 2004.

Joughin, I., Howat, I. M., Fahnestock, M., Smith, B., Krabill, W., Alley, R. B., Stern, H., and Truffer, M.: Continued evolution of Jakobshavn Isbrae following its rapid speedup, J. Geophys. Res., 113, F04006, doi:10.1029/2008JF001023, 2008.

Joughin, I., Smith, B. E., Howat, I. M., Scambos, T., and Moon, T.: Greenland flow variability from icesheet-wide velocity mapping, J. Glaciol., 56, 415-430, doi:10.3189/002214310792447734, 2010.

Khan, S. A., Wahr, J., Bevis, M., Velicogna, I., and Kendrick, E.: Spread of ice mass loss into Northwest Greenland observed by GRACE and GPS, Geophys. Res. Lett., 37, L06501, doi:10.1029/2010GL042460, 2010.

Krabill, W., Frederick, E., Manizade, S., Martin, C., Sonntag, J., Swift, R., Thomas, R., Wright, W., and Yungel, J.: Rapid thinning of parts of the Southern Greenland Ice Sheet, Science, 283, 1522-1524, doi:10.1126/science.283.5407.1522, 1999.

Krabill, W., Abdalati, W., Frederick, E., Manizade, S., Martin, C., Sonntag, J., Swift, R., Thomas, R., Wright, W., and Yungel, J.: Greenland Ice Sheet: high-elevation balance and peripheral thinning, Science, 289, 428-430, 2000.

Krabill, W., Hanna, E., Huybrechts, P., Abdalati, W., Cappelen, J., Csatho, B., Frederick, E., Manizade, S., Martin, C., Sonntag, J., Swift, R., Thomas, R., and Yungel, J.: Greenland Ice Sheet: increased coastal thinning, Geophys. Res. Lett., 31, L24402, doi:10.1029/2004GL021533, 2004.

Le Brocq, A. M., Payne, A. J., and Siegert, M. J.: West Antarctic balance calculations: impact of flux-routing algorithm, smoothing algorithm and topography, Comput. Geosci., 32, 1780-1795, doi:10.1016/j.cageo.2006.05.003, 2006.

Levene, H.: Robust tests for equality of variances, in: Contributions to Probability and Statistics: Essays in Honor of Harold Hotelling, edited by: I. Olkin, S. G. Ghurye, W. Hoeffding and W. G. Madow, Stanford University Press, Stanford, Calif., 278292, 1960

Lucchitta, B. K., Rosanova, C. E., and Mullins, K. F.: Velocities of Pine Island Glacier, West Antarctica, from ERS-1 SAR images, Ann. Glaciol., 21, 277-283, 1995.

Luckman, A. and Murray, T.: Seasonal variations in velocity before retreat of Jakobshavn Isbrae, Greenland, Geophys. Res. Lett., 32, L08501, doi:10.1029/2005GL022519, 2005.

Luckman, A., Murray, T., Jiskoot, H., Pritchard, H., and Strozzi, T.: ERS SAR feature-tracking measurement of outlet glacier velocities on a regional scale in East Greenland, Ann. Glaciol., 36, 129-134, doi:10.3189/172756403781816428, 2003.

Luckman, A., Murray, T., de Lange, R., and Hanna, E.: Rapid and synchronous ice-dynamic changes in East Greenland, Geophys. Res. Lett., 33, L03503, doi:10.1029/2005GL025428, 2006.

Luthcke, S. B., Zwally, H. J., Abdalati, W., Rowlands, D. D., Ray, R. D., Nerem, R. S., Lemoine, F. G., McCarthy, J. J., and Chinn, D. S.: Recent Greenland ice mass loss by drainage system from satellite gravity observations, Science, 314, 1286-1289, doi:10.1126/science.1130776, 2006.
Mayer, C., Reeh, N., Jung-Rothenhäusler, F., Huybrechts, P., and Oerter, H.: The subglacial cavity and implied dynamics under Nioghalvfjerdsfjorden Glacier, NE-Greenland, Geophys. Res. Lett., 27, 2289-2292, doi:10.1029/2000GL011514, 2000.

McFadden, E. M., Howat, I. M., Joughin, I., Smith, B. E., and Ahn, Y.: Changes in the dynamics of marine terminating outlet glaciers in West Greenland (2000-2009), J. Geophys. Res., 116, F02022, doi:10.1029/2010JF001757, 2011.

Moon, T. and Joughin, I.: Changes in ice front position on Greenland's outlet glaciers from 1992 to 2007, J. Geophys. Res., 113, F02022, doi:10.1029/2007JF000927, 2008.

Motyka, R. J., Hunter, L., Echelmeyer, K. A., and Connor, C.: Submarine melting at the terminus of a temperate tidewater glacier, LeConte Glacier, Alaska, USA, Ann. Glaciol., 36, 5765, doi:10.3189/172756403781816374, 2003.

Motyka, R. J., Truffer, M., Fahnestock, M., Mortensen, J., Rysgaard, S., and Howat, I.: Submarine melting of the 1985 Jakobshavn Isbræ floating tongue and the triggering of the current retreat, J. Geophys. Res., 116, F01007, doi:10.1029/2009JF001632, 2011.

Münchow, A., Falkner, K. K., Melling, H., Rabe, B., and Johnson, H. L.: Ocean warming of Nares Strait bottom waters off Northwest Greenland, 2003-2009, Oceanography, 24, 114-123, 2011.

Murray, T., Scharrer, K., James, T. D., Dye, S. R., Hanna, E., Booth, A. D., Selmes, N., Luckman, A., Hughes, A. L. C., Cook, S., and Huybrechts, P.: Ocean regulation hypothesis for glacier dynamics in Southeast Greenland and implications for ice sheet mass changes, J. Geophys. Res., 115, F03026, doi:10.1029/2009JF001522, 2010.

Nick, F. M., Vieli, A., Howat, I. M., and Joughin, I.: Large-scale changes in Greenland outlet glacier dynamics triggered at the terminus, Nat. Geosci., 2, 110-114, doi:10.1038/ngeo394, 2009.

Nick, F. M., van der Veen, C. J., Vieli, A., and Benn, D. I.: A physically based calving model applied to marine outlet glaciers and implications for the glacier dynamics, J. Glaciol., 56, 781-794, doi:10.3189/002214310794457344, 2010.

Nick, F. M., Luckman, A., Vieli, A., der Veen, V., van As, D., de Wal, V., Pattyn, F., Hubbard, and Floricioiu, D.: The response of Petermann Glacier, Greenland, to large calving events, and its future stability in the context of atmospheric and oceanic warming, J. Glaciol., 58, 229-239, doi:10.3189/2012JoG11J242, 2012.

Nilsson, J., Björk, G., Rudels, B., Winsor, P., and Torres, D.: Liquid freshwater transport and polar surface water characteristics in the East Greenland current during the AO-02 Oden expedition, Prog Oceanogr., 78, 45-57, doi:10.1016/j.pocean.2007.06.002, 2008.

Pritchard, H., Murray, T., Luckman, A., Strozzi, T., and Barr, S.: Glacier surge dynamics of Sortebræ, East Greenland, from synthetic aperture radar feature tracking, J. Geophys. Res., 110, F03005, doi:10.1029/2004JF000233, 2005.

Pritchard, H. D., Arthern, R. J., Vaughan, D. G., and Edwards, L. A.: Extensive dynamic thinning on the margins of the Greenland and Antarctic ice sheets, Nature, 461, 971-975, doi:10.1038/nature08471, 2009.

Reeh, N., Thomsen, H. H., Higgins, A. K., and Weidick, A.: Sea ice and the stability of North and Northeast Greenland floating glaciers, Ann. Glaciol., 474-480, doi:10.3189/172756401781818554, 2001. 
Reynolds, R. W., Smith, T. M., Liu, C., Chelton, D. B., Casey, K. S., and Schlax, M. G.: Daily high-resolution-blended analyses for sea surface temperature, J. Climate, 20, 5473-5496, doi:10.1175/2007JCLI1824.1, 2007.

Rignot, E. and Kanagaratnam, P.: Changes in the velocity structure of the Greenland Ice Sheet, Science, 311, 986-990, doi:10.1126/science.1121381, 2006.

Rignot, E., Gogineni, S., Joughin, I., and Krabill, W.: Contribution to the glaciology of Northern Greenland from satellite radar interferometry, J. Geophys. Res., 106, D24, doi:10.1029/2001JD900071, 2001.

Rignot, E., Braaten, D., Gogineni, S. P., Krabill, W. B., and McConnell, J. R.: Rapid ice discharge from Southeast Greenland glaciers, Geophys. Res. Lett., 31, L10401, doi:10.1029/2004GL019474, 2004.

Rignot, E., Koppes, M., and Velicogna, I.: Rapid submarine melting of the calving faces of West Greenland glaciers, Nat. Geosci., 3, 187-191, doi:10.1038/ngeo765, 2010.

Rignot, E., Velicogna, I., van den Broeke, M. R., Monaghan, A., and Lenaerts, J.: Acceleration of the contribution of the Greenland and Antarctic ice sheets to sea level rise, Geophys. Res. Lett., 38, L05503, doi:10.1029/2011GL046583, 2011.

Scambos, T. A., Dutkiewicz, M. J., Wilson, J. C., and Bindschaler, R. A.: Application of image cross-correlation to the measurement of glacier velocity using satellite image data, Remote Sens. Environ., 42, 177-186, 1992.

Schrama, E. J. O. and Wouters, B.: Revisiting Greenland Ice Sheet mass loss observed by GRACE, J. Geophys. Res., 116, B202407, doi:10.1029/2009JB006847, 2011.

Schrama, E., Wouters, B., and Vermeersen, B.: Present day regional mass loss of Greenland observed with satellite gravimetry, Surv. Geophys., 1-9, doi:10.1007/s10712-011-9113-7, 2011.

Seale, A., Christoffersen, P., Mugford, R. I., and O'Leary, M.: Ocean forcing of the Greenland Ice Sheet: calving fronts and patterns of retreat identified by automatic satellite monitoring of eastern outlet glaciers, J. Geophys. Res., 116, F03013, doi:10.1029/2010JF001847, 2011.

Sole, A., Payne, T., Bamber, J., Nienow, P., and Krabill, W.: Testing hypotheses of the cause of peripheral thinning of the Greenland Ice Sheet: is land-terminating ice thinning at anomalously high rates?, The Cryosphere, 2, 205-218, doi:10.5194/tc-2-205-2008, 2008.

Stearns, L. A., Hamilton, G. S., and Reeh, N.: Multi-decadal record of ice dynamics on Daugaard Jensen Gletscher, East Greenland, from satellite imagery and terrestrial measurements, Ann. Glaciol., 42, 53-58, doi:10.3189/172756405781812565, 2005.

Straneo, F., Hamilton, G. S., Sutherland, D. A., Stearns, L. A., Davidson, F., Hammill, M. O., Stenson, G. B., and RosingAsvid, A.: Rapid circulation of warm subtropical waters in a major glacial fjord in East Greenland, Nat. Geosci., 3, 182-186, doi:10.1038/ngeo764, 2010.

Straneo, F., Curry, R. G., Sutherland, D. A., Hamilton, G. S., Cenedese, C., Vage, K., and Stearns, L. A.: Impact of fjord dynamics and glacial runoff on the circulation near Helheim Glacier, Nat. Geosci., 4, 322-327, doi:10.1038/ngeo1109, 2011.
Strozzi, T., Luckman, A., Murray, T., Wegmüller, U., and Werner, C. L.: Glacier motion estimation using SAR offsettracking procedures, IEEE T. Geosci. Remote, 40, 2384-2391, 2002.

Sutton, R. T. and Hodson, D. L. R.: Atlantic Ocean forcing of North American and European summer climate, Science, 309, 115118, doi:10.1126/science.1109496, 2005.

Thomas, R., Atkins, T., Csatho, B., Fahnestock, M., Gogineni, P., Klim, C., and Sonntag, J.: Mass balance of the Greenland Ice Sheet at high elevations, Science, 289, 426-428, 2000.

Thomas, R. H., Abdalati, W., Frederick, E., Krabill, W. B., Manizade, S., and Steffen, K.: Investigation of surface melting and dynamic thinning on Jakobshavn Isbrae, Greenland, J. Glaciol., 231-239, doi:10.3189/172756503781830764, 2003.

Thomas, R., Frederick, E., Krabill, W., Manizade, S., and Martin, C.: Progressive increase in ice loss from Greenland, Geophys. Res. Lett., 33, L10503, doi:10.1029/2006GL026075, 2006.

Thomas, R., Frederick, E., Li, J., Krabill, W., Manizade, S., Paden, J., Sonntag, J., Swift, R., and Yungel, J.: Accelerating ice loss from the fastest Greenland and Antarctic glaciers, Geophys. Res. Lett., 38, L10502, doi:10.1029/2011GL047304, 2011.

van den Broeke, M., Bamber, J., Ettema, J., Rignot, E., Schrama, E., van de Berg, W. J., van Meijgaard, E., Velicogna, I., and Wouters, B.: Partitioning recent Greenland mass loss, Science, 326, 984-986, doi:10.1126/science.1178176, 2009.

van den Broeke, M., Bamber, J., Lenaerts, J., and Rignot, E.: Ice sheets and sea level: thinking outside the box, Surv. Geophys., 32, 495-505, doi:10.1007/s10712-011-9137-z, 2011.

van der Veen, C. J., Plummer, J. C., and Stearns, L. A.: Controls on the recent speed-up of Jakobshavn Isbrae, West Greenland, J. Glaciol., 57, 770-782, 2011.

Velicogna, I.: Increasing rates of ice mass loss from the Greenland and Antarctic ice sheets revealed by GRACE, Geophys. Res. Lett., 36, L19503, doi:10.1029/2009GL040222, 2009.

Velicogna, I. and Wahr, J.: Greenland mass balance from GRACE, Geophys. Res. Lett., 32, L18505, doi:10.1029/2005GL023955, 2005.

Wake, L. M., Huybrechts, P., Box, J. E., Hanna, E., Janssens, I., and Milne, G. A.: Surface mass-balance changes of the Greenland Ice Sheet since 1866, Ann. Glaciol., 50, 178-184, doi:10.3189/172756409787769636, 2009.

Walsh, K. M., Howat, I. M., Ahn, Y., and Enderlin, E. M.: Changes in the marine-terminating glaciers of central east Greenland, 2000-2010, The Cryosphere, 6, 211-220, doi:10.5194/tc-6-2112012, 2012.

Wouters, B., Chambers, D., and Schrama, E. J. O.: GRACE observes small-scale mass loss in Greenland, Geophys. Res. Lett., 35, L20501, doi:10.1029/2008GL034816, 2008.

Yin, J., Overpeck, J. T., Griffies, S. M., Hu, A., Russell, J. L., and Stouffer, R. J.: Different magnitudes of projected subsurface ocean warming around Greenland and Antarctica, Nat. Geosci., 4, 524-528, doi:10.1038/ngeo1189, 2011. 